\title{
Financial Inclusion in India and PMJDY: A Critical Review
}

\author{
Kumar Bijoy \\ Shaheed Sukhdev College of Business Studies - University of Delhi
}

\begin{abstract}
The recent developments in banking and insurance have transformed the financial system, however, it is restricted only to certain segments of the society, excluding others. i.e. "financial exclusion". People with low incomes, cannot access mainstream financial products such as bank accounts, credit, remittances and payment services, financial advisory services, insurance facilities, etc. This situation is detrimental for a nation's economy as micro savings are not properly channelized into the productive sectors of the economy. This study explores to find the current status of financial inclusion in India, analyze the government's effort through various policies like MGNREGA, DBT, PMJDY etc. The study is based on secondary information from the Governmental committees' reports and primary information from six states of India before the launch of PMJDY. The post PMJDY status is reviewed only through the secondary information published in Government reports. It is found that PMJDY has increased the number of Bank accounts through diluting KYC for marginalized and deprived citizens but transactions in the account is very limited. A good number of accounts are dormant in the want of sufficient income to be routed through that account or lack of savings to be deposited. It is recommended to policy makers to concentrate on the creation of job opportunities for all to have complete financial inclusion in India.
\end{abstract}

Index Terms-Financial Inclusion, PMJDY, KYC, Financial Services, Sufficient income

\section{INTRODUCTION}

$\mathrm{F}$ INANCIAL Stability of an economy depends on three important pillars: Financial Inclusion, Financial Literacy and Consumer Protection. Financial Inclusion, broadly defined, refers to universal access to a wide range of financial services by all sections of the society in general and vulnerable groups such as weaker sections and low income groups at a reasonable cost. These include not only banking products but also other financial services such as insurance and equity products. Every one's participation in formal financial service sector is the root of financial inclusion.

A well-established financial system is the effective circulatory system of economy. It empowers individuals to access the various facilities of the system in more efficient manner and contribute maximum to the system where-ever possible. This makes the system robust and economic shocks proof. Success of financial inclusion lies in achievements of three steps: 1. Bank Account to at least one member of a household; 2. Regular deposit and withdrawals under that bank account and 3. The Bank Account is used for transactions payment. In addition, system should take care of facility and security aspects so that individuals should be free from all worries with respect to product pricing (interest rates on deposits and loans, transaction fee, penalty on delay etc.), ease of availability of products, ease of transactions and security at every steps. Financial Inclusion should help vulnerable groups such as low income groups, weaker sections, etc., to increase incomes, acquire capital, manage risk and work their way out of poverty. Various steps are being taken by the government over the years but still the problem of financial exclusion looms large and is the root cause of persistent mass poverty in India. This may be due to the skewed effort of the government i.e. focusing mainly on the supply side and ignoring the demand side of financial inclusion. In order to achieve this demand side efforts need to be taken including improving human and physical resource endowments, enhancing productivity, mitigating risk and strengthening market linkages. However, the primary focus is on improving the delivery systems, both conventional and innovative.

\section{A. Global Scenario}

The United Nations (UN) in its landmark research work titled "Building Inclusive Financial Sectors for Development"1 (2006), popularly known as the Blue Book, had raised the basic question: "why are so many bankable people unbanked?" As per the Blue Book an inclusive financial sector, would provide access to credit for all "bankable" people and firms, to insurance for all insurable people and firms and to savings and payments services for everyone. "Financial inclusion, thus, has become an issue of worldwide concern and relevant for all (under-developed, developing and developed nations). According to GLOBAL FINANCIAL DEVELOPMENT REPORT 2014 more than 2.5 billion adults - about half of the world's adult population - do not have a bank account. While some of these people exhibit no demand for accounts, most are excluded because of barriers such as cost, travel distance, and amount of paperwork. Enterprise surveys in 137 countries find that only 34 percent of firms in developing economies have a bank loan, whereas the share is 51 percent in developed economies. In develop- 
ing economies, 35 percent of small firms identify finance as a major constraint, while only 16 percent in developed economies do so.

\section{B. Developed Nations:}

USA passed The Community Reinvestment Act, 1977 and Matched Savings Scheme (MSS) 1997 to Prohibit discrimination by banks against low and moderate income neighborhoods; to make mortgage loans to lower-income households. The Act also ensures that banks are rated every three years on their efforts in meeting community credit needs. France introduced Banking Act, 1984 which has provides right to any person with French nationality to open an account with any bank and if refused the aggrieved person can apply to the Banque de France to designate a bank that should open an account. Further, French Banker's Association (Basic Banking Service Charter of 1992) committed to provide affordable account, Cash Card, Free access to a cash machine, Distance payment facilities, Bank Statement and Negotiable number of cheques to all citizens. United Kingdom in 1997 established: Social Exclusion Unit (SEU) to reduce social exclusion; Policy Action Teams (PATs) to look in an integrated way at the problems of poor neighborhoods; Financial Inclusion Task Force to ensure access to banking, affordable credit and access to face-to-face money advice and Financial Inclusion Fund to make the drive feasible. Australia through Australian Bankers Association (ABA) Code of Practice, 1995 and Rural Transformation Centre Programme (RTCP) is providing banking and other transaction services to communities without banking facilities. For this they are using existing stores and post offices or standalone centres and installing Electric Point of Sale (EPOS) equipment in post offices. Belgium has Charter of Basic Banking Services, 1996 which provide a basic bank account with no minimum balance and without overdraft facilities but enabled with credit transfers, direct debits, and deposit and withdrawal facilities. In Canada, Access to Basic Banking Services Regulations, 2003 enables Personal bank accounts to all Canadians regardless of employment or credit history and with minimum identification requirements and arranges for Banks/FIs to encash government cheques at no charge.

Note:

1. The book is a result of a project undertaken by the UN Department of Economic and Social Affairs (DESA) and the UN Capital Development Fund (UNCDF) to analyze the obstacles to financial inclusion and to report on efforts to overcome those obstacles in various countries.

Developing and Underdeveloped Nations are also trying their best to finish financial exclusion. Kenya introduced M-Pesa to use the mobile phone company as a conduit for keeping and transacting money. It is Bank without a Bank. However, it can't use that money and the customers don't get any interest. Safaricom-Vodafone launched MPESA in 2007 creating this parallel banking ecosystem. The transactions, capped at $\$ 500$, happen in real time through a wide network of agents. Since May 2010, Safaricom has ventured into providing deposit facility too by tying up with Equity Bank. The "M-KESHO" savings account, as it is called, too can be accessed from a customer's mobile phone. South Africa being one of the most expensive banking markets asked a collective of five banks to launch 'no-frill' bank account scheme in 2004, the Mzansi account has no monthly fees. Five transactions in a month are free. According to a 2009 report by the non-profit Fin Mark Trust, there are 6 million Mzansi accounts in a country of 32 million. Brazil introduced Branchless banking through agents called banking correspondents (BCs). In 1997, as many as 40 million Brazilians out of the total 62 million did not have access to any financial services. Over the last decade, the model has grown rapidly and 150,000 BCs account for about 62 percent of the total number of points of service in the financial system. It is the world's largest such network and the total number of bank accounts has doubled between 2000 and 2008, from 63.7 million to 125.7 million. Philippines with two-third of population below poverty line and only $20 \%$ of the population have access to bank accounts, has adopted an approach of extensive use of Electronic money and Mobile Banking for Financial Inclusion in no bank area. E-money is used for transactions and can be recharged from cash in cash out joint. China addressed the issue of financial exclusion by introducing China Union Pay, a domestic payment network which would accelerate adoption of credit and debit cards in China in 2002. The total transactions through CUP has reached USD 1.9 trillion and are accepted in over 150 countries across the globe. The support from government, support from local banks, sound technological standards and most important, right value proposition for the ignored regional banks is the key to the success of CUP.

\section{Indian Scenario:}

First major step towards financial inclusion started with nationalization of banks in 1969 followed by establishment of Priority Sector Lending Banks in 1971 and Regional Rural Banks in 1975. Further banking penetration in rural India was tried through establishing National Bank for Agricultural and Rural Development in 1982. In addition to these institutional architecture, structural arrangements were initiated in 1992 by launching Self Help Groups Bank Linkage Program. Establishment of Small Industries Development Bank of India foundation for Micro Credit in the year 2000 and of Micro unit development \& refinance agency ltd. (Mudra) in 2016 are new milestones towards the same.

Committees on Financial Inclusion: Indian Government has kept on addressing the issues of financial exclusion through various committees since independence. Some of them were directly addressing the issues of exclusion whereas others are creating the favorable condition for inclusion. Some of the committees are - A C Shah Committee: NBFC; A Ghosh Committee: Frauds \& Malpractices 
In Banks; B Sivaraman Committee: Institutional Credit For Agricultural \& Rural Development; B Venkatappaiah Committee: All India Rural Credit Review; Bhagwati Committee: Unemployment; Chatalier Committee: Finance To Small Scale Industry; DR Gadgil Committee: Agricultural Finance; Godwala Committee: Rural Finance; Khusrau Committee: Agricultural Credit; Mahalanobis Committee: Income Distribution; Narsimham Committee: Financial System; Purshottam Das Committee: Agricultural Finance And Cooperative Societies; R S Saria Committee: Agricultural Finance And Cooperative Societies; RN Malhotra Committee: Reforms In Insurance Sector; RN Mirdha Committee: Cooperative Societies; RV Gupta Committee: Agricultural Credit Delivery; UK Sharma Committee: Lead Bank Scheme (Review); Usha Thorat Panel: Financial Inclusion; Venketaiya Committee: Review Of Rural Financing System; YV Reddy Committee: Reforms In Small Savings; Dr. C. Rangarajan: Estimation of Savings and Investment; Deepak Mohanty Committee: Medium-term Path on Financial Inclusion. The final suggestions of all these are to make India a more financially inclusive country.

\section{Prime Minister Jan Dhan Yojna (PMJDY):}

However, a transformational decision was taken by the Prime minister of India in the form of Pradhan Mantri Jan Dhan Yojana (PMJDY) on 28 August 2014. The main objective of this scheme is to ensure universal access to banking facilities with at least one basic bank account for every household. The scheme is based on "Sab ka sath sab ka vikas" i.e. inclusive growth through "Mera Khata Bhagya Vidhata'. Under the scheme, account holders will be provided zero-balance bank account with RuPay debit card and in addition an accidental insurance cover of Rs 1 lakh. Those who open accounts by January 26, 2015 over and above the Rs1 lakh accident, they will be given life insurance cover of Rs 30,000. Six months of opening of the bank account, holders can avail Rs 5,000 overdraft facility. The PMJDY scheme in addition to bank accounts offer overdraft facility, Insurance products and direct benefit transfer.

\section{Review of Literature:}

Jeromi (2007) highlighted the issue of financial exclusion from formal sector and proliferation of informal financial institutions and money lenders in Kerala and invited the attention towards the social, political and economic issues arising out of this situation. C Rangarajan (2008) through his committee report emphasized the need to modify the credit and financial services delivery system to achieve greater inclusion. He further suggested that while banks and other financial institutions can also take some efforts on their own to improve the absorptive capacity of the clients, it is equally important for Government at various levels to initiate actions to enhance the earnings capacity of the poorer sections of the society. The two together can bring about the desired change of greater inclusion quickly. Raghuram G. Rajan
(2009) through his committee on financial sector reforms discussed in Chapter 3 (of report), the issue of financial inclusion and proposes a paradigm shift in the way we see inclusion. Instead of seeing it as an expanding credit, they urge to see it as expanding access to financial services, such as payments services, savings products, insurance products, and inflation-protected pensions. The Committee advocates a national goal of ensuring in three years that 90 per cent of households, if they so desire, have access to a deposit account and to the payments system, and that government transfers under various schemes be implemented through this system. Misra (2010) studied the various models for financial inclusion in different countries. Malegam (2011) through his committee report on Microfinance suggested the number of steps to strengthen financial inclusion in the country. Arulmurugan et. al. (2013) tried to study the various efforts for financial inclusion in India whereas Sharma \& kukreja (2013) in their study focused on the relevance of financial inclusion in strengthening the India's position in relation to other countries economy. Krishna kumar \& Vijaya kumar (2013) focused in their study on effectiveness of Financial Inclusion products and programs. Thapar (2013) in her study concluded that though the banks are complying with RBI norms in terms of opening branches within areas of at least 2000 population, offering no frills account, kissan credit card, simplifying KYC norms, but still a lot of effort is to be put in for financial inclusion progress. Nachiket Mor (2014) as mandated to develop a comprehensive monitoring framework to track the progress of the financial inclusion and deepening efforts on a nationwide basis and suggested many steps to strengthen the process of inclusion. Singh \& Nisha (2014) in their study established a direct relationship between human development and financial inclusion. They further highlighted the importance of physical infrastructure for connectivity \& information and Government policies for financial inclusion.

\section{A. Research Problem/Hypothesis/ Objectives}

The review of previous studies clearly indicate that various steps are being taken by the government over the years but still the problem of financial exclusion looms large. Most of the rural India doesn't have access to banks, and even if they have after PMJDY they don't have enough income and awareness/financial literacy to use the financial services.

Our objective is to study the state of financial inclusion in India through secondary and primary study and point out the weak links in the current structure and also come up with ways to counter these weak links. We aim to cover both demand and supply side problems.

\section{Data and Methodology}

Data is collected both from secondary and primary sources. 


\section{Secondary source:}

Information on measures taken by the government in the past 20 years and progress on governmental schemes in the light of prevailing regulatory environment as well as data of micro-finance and micro-insurance in the country and some other developed and emerging economies. All the information is collected through published sources. Key sources are:

[1] Government key advisory group reports like Nachiket Mor committee report, etc.

[2] Private sector consultancy companies reports like reports by BCG, Mckinsey, etc.

[3] Data published by banks at various levels like RBI, Lead Bank, NABARD.

[4] Data Published by World Bank

[5] Reports on successful financial inclusion in other countries

\section{Primary Source:}

Information through direct interaction with people and getting response recorded from various locations of India. A questionnaire is developed (see annexure at the end) to get first-hand information on extent of financial inclusion in India. Questions included - Personal Information; Basic access to financial system; Usage of Banks; Usage of Insurance.

\section{A. Methodology}

The study is based on the survey conducted in the 6 states namely Himachal Pradesh, Haryana, Delhi, Uttar Pradesh, Bihar and Jharkhand and views of people (belonging to very low income group) in villages around Shimla, Panipat, Sonipat, Mathura, Vrindavan, Kanpur, Biddupur (near Patna), and Dhanbad are recorded through questionnaires. All respondents are compulsorily of Below Poverty Line (BPL) category. Then the data collected through questionnaire is analyzed using SPSS software. Statistical results are analyzed to find out the real picture of financial inclusion in India.

The information available from secondary sources (various reports) and primary survey before PMJDY and secondary sources after PMJDY is used to draw conclusion and suggest some solution for improving financial inclusion conditions.

\section{Research Findings:}

As the majority of the rural population is still not included in the inclusive growth, the concept of financial inclusion becomes a challenge for the Indian economy. Since early 2000 s, many concerted measures are initiated by the Reserve Bank of India and Government of India in favor of financial inclusion. Measures such as Self Help Group-Bank Linkage program (SHG-BLP), use of business facilitators and correspondents (BC-BF), easing of Know Your Customer (KYC) norms, Direct Benefit Transfer (DBT), sepa- rate plan for urban financial inclusion, use of mobile technology, bank branches and ATMs, opening and encouraging 'no-frill-accounts' and emphasis on financial literacy have played a significant role for increasing the use of formal sources for availing loan/ credit. Measures initiated by the government include, opening customer service centers, credit counselling centers, Kisan Credit Card (KCC), Mahatma Gandhi National Rural Employment Guarantee Act (MGNREGA) Scheme and Aadhar Scheme. These renewed efforts are more focused than the earlier measures which were more general in nature having a much wider scope.

Below is a list of major schemes adopted by the Government and the RBI to promote financial inclusion. The list also gives the major pros and cons of each scheme.

The G20 Financial Inclusion Action Plan (FIAP) (2017) is one of the most important guiding documents for the financial inclusion movement as they move rapidly to expand affordable, effective, and safe financial services to the two billion people and 200 million businesses that remain excluded from the financial system. The Global Partnership for Financial Inclusion (GPFI) suggests the implementation of the G20 Financial Inclusion Action Plan (FIAP) by its four Subgroups: (1) SME Finance, (2) Regulation and Standard-Setting Bodies, (3) Financial Consumer Protection and Financial Literacy, and (4) Markets and Payment Systems. This is the most recent action plan for financial inclusion at global level.

\section{Primary Study results:}

The research conducted in the 6 states of Himachal Pradesh, Haryana, Delhi, Uttar Pradesh, Bihar and Jharkhand and views of more than 600 people in the villages around Mathura, Vrindavan, Shimla and Dhanbad were recorded through questionnaires.
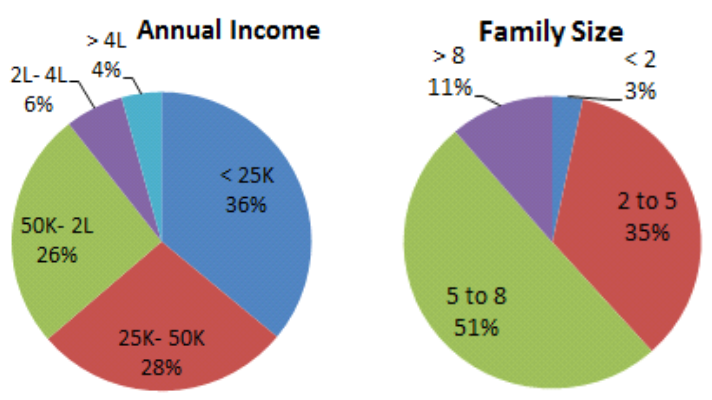

The average family size was 7 members with almost $50 \%$ of the people interviewed being either illiterate or educated only up to class 8 . Respondents were mostly agricultural or construction laborers usually earning an income less than Rs. 25000 per annum. $41 \%$ people did not had any bank account whereas $50 \%$ had an account at some bank branch within $2 \mathrm{~km}$ radius from their homes. The primary reason for not having bank account was lack of sufficient and stable income. 
Table: Summary of Schemes operational in India (Secondary data)

\begin{tabular}{|c|c|c|c|}
\hline Scheme & Program & Findings & Remarks \\
\hline $\begin{array}{l}\text { Kissan Credit } \\
\text { Card and } \\
\text { General Credit } \\
\text { Card }\end{array}$ & $\begin{array}{l}\text { - Includes Rashtriya Krishi } \\
\text { Bima Yojana cover } \\
\text { - Gives farmers freedom to } \\
\text { use cash in any manner (no } \\
\text { need to submit bill receipts) }\end{array}$ & $\begin{array}{l}\bullet \text { Heavy subsidy by the government. } \\
\text { (Rs 30,000 crore waiver in 2008) } \\
\text { • Many farmers default in hope of } \\
\text { availing waivers } \\
\text { • Use of loan amount for } \\
\text { consumption instead of agriculture }\end{array}$ & $\begin{array}{l}\text { In case of GCC } \\
\text { Credit up to Rs } \\
25000 \text { without } \\
\text { security offered }\end{array}$ \\
\hline BC-BF Model & $\begin{array}{l}\text { - Allows door-step delivery } \\
\text { of financial services } \\
\text { - Deposit, withdrawal and } \\
\text { even remittance services } \\
\text { provided } \\
\text { - Relaxed KYC norms }\end{array}$ & $\begin{array}{l}\text { - High attrition rate of } \mathrm{BCs} \\
\text { - Lack of trust between banks and } \\
\text { agents } \\
\text { - Banks held responsible for BCs } \\
\text { misdeeds } \\
\text { - Govt. placed cap on interest } \\
\text { - Govt. placed cap on service area } \\
\text { (5km urban, 30km rural) } \\
\text { - Daily reporting norm- an } \\
\text { impediment } \\
\text { - Commission structure cannot cover } \\
\text { costs }\end{array}$ & \\
\hline $\begin{array}{l}\text { Ultra-Small } \\
\text { Branches }\end{array}$ & $\begin{array}{l}\text { - Tackles 'last-mile' } \\
\text { connectivity problem }\end{array}$ & $\begin{array}{l}- \text { Limited services offered on limited } \\
\text { days }\end{array}$ & $\begin{array}{l}50,000 \text { such } \\
\text { branches setup by } \\
\text { march } 2013\end{array}$ \\
\hline SHG-BLP & $\begin{array}{l}\bullet \text { High recovery rate of loans } \\
- \text { Reduced dependency on } \\
\text { informal sources of debt }\end{array}$ & $\begin{array}{l}\text { - Interest rates are high } \\
\text { - Ever-greening of loans } \\
\text { - Size of loans given to members is } \\
\text { generally too small to undertake any } \\
\text { meaningful activity } \\
\text { - Wide regional disparity ( } 48 \% \text { of } \\
\text { SHGs in Southern Region) }\end{array}$ & \\
\hline $\begin{array}{l}\text { Direct Benefit } \\
\text { Transfer (DBT) }\end{array}$ & $\begin{array}{l}\text { - Removes middlemen in } \\
\text { cash disbursement } \\
\text { - If Aadhaar authentication } \\
\text { equated to KYC, work is } \\
\text { reduced significantly } \\
\text { - If online Aadhaar } \\
\text { authentication is adopted, } \\
\text { number of service points for } \\
\text { banks increase }\end{array}$ & $\begin{array}{l}\text { - Aadhaar enrollment camps can be } \\
\text { leveraged to open bank accounts for } \\
\text { people } \\
\text { - Not all beneficiaries have bank } \\
\text { accounts } \\
\text { - Requires connectivity at all times } \\
\text { for processing transactions }\end{array}$ & \\
\hline $\begin{array}{l}\text { USSD Mobile } \\
\text { Banking }\end{array}$ & $\begin{array}{l}\text { - Provides banking facilities } \\
\text { like Money Transfer, Bill } \\
\text { Payments, Balance } \\
\text { Enquiries, Merchant } \\
\text { payments etc }\end{array}$ & $\begin{array}{l}\text { - Works only with updated GSM } \\
\text { phones }\end{array}$ & $\begin{array}{l}\text { Unstructured } \\
\text { Supplementary } \\
\text { service data } \\
\text { technology used. } \\
\text { Is like SMS, but } \\
\text { without cost for } \\
\text { the user }\end{array}$ \\
\hline RRBs & $\begin{array}{l}\text { - Enhances reach of formal } \\
\text { banking system in rural } \\
\text { areas }\end{array}$ & $\begin{array}{l}\text { - High transaction cost due to large } \\
\text { number of small accounts } \\
\text { - Low interest income due to } \\
\text { concessional rates charged }\end{array}$ & \\
\hline $\begin{array}{l}\text { No Frills } \\
\text { Accounts- } \\
\text { Directive by RBI }\end{array}$ & $\begin{array}{l}\text { - Provides access to all to } \\
\text { enter formal banking system }\end{array}$ & $\begin{array}{l}\text { - Accounts are created and left } \\
\text { unused } \\
\text { - Providing this service is a loss } \\
\text { making activity for banks }\end{array}$ & \\
\hline MGNREGA & $\begin{array}{l}\text {-Undertake useful } \\
\text { development projects }\end{array}$ & $\begin{array}{l}\text { - Misappropriation of funds by } \\
\text { middlemen } \\
\text { - Fraud (by those availing the } \\
\text { scheme) } \\
\text { - Heavy burden on exchequer (Rs } \\
34,000 \text { crore in } 2014-15 \text { budget) }\end{array}$ & \\
\hline
\end{tabular}




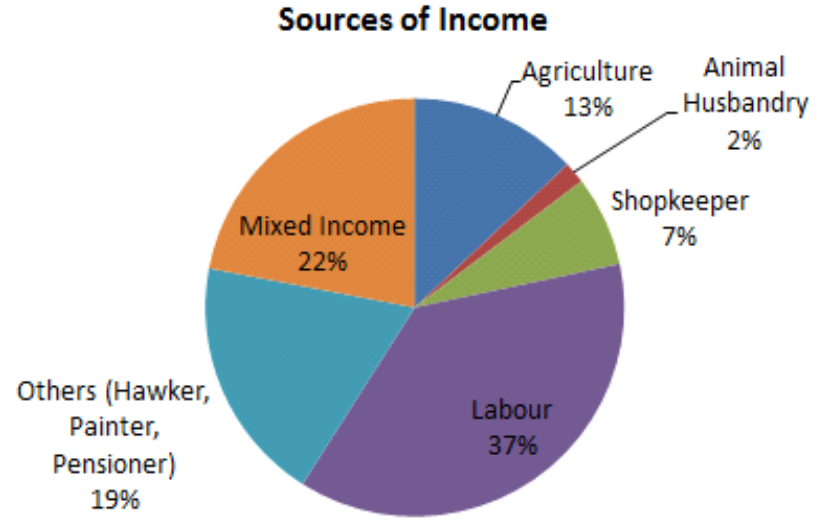

They faced multiple problems while taking a loan from banks and remain deprived from the bank loans. Some of the prominently sited reasons were:

- Cumbersome document requirements (cited by $18 \%$ )

- Harassment from the bank officials for obtaining a loan $(7 \%)$

- collateral requirements

- Lack of trust

-Afraid of the bank's harsh loan recovery processes

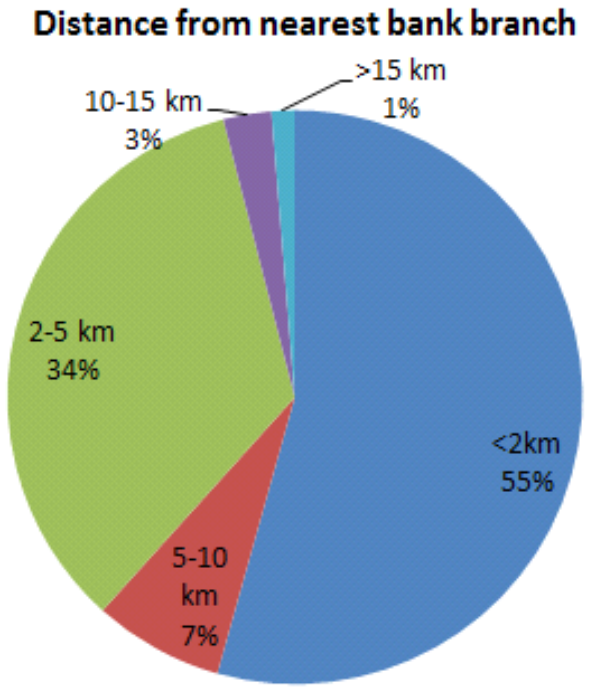

They had difficulty in availing bank loans without help from a middleman who then charged a commission of $\mathbf{1 0 \%}$ on the loan amount. $\mathbf{5 8 \%}$ owned and used a mobile out of which only $\mathbf{3 \%}$ used their mobile for transaction purposes. Most of the users of transactions through mobile were from Delhi and Haryana sample. $\mathbf{7 2 \%}$ said they were not associated with any welfare scheme and were of the view

\section{Insurance}
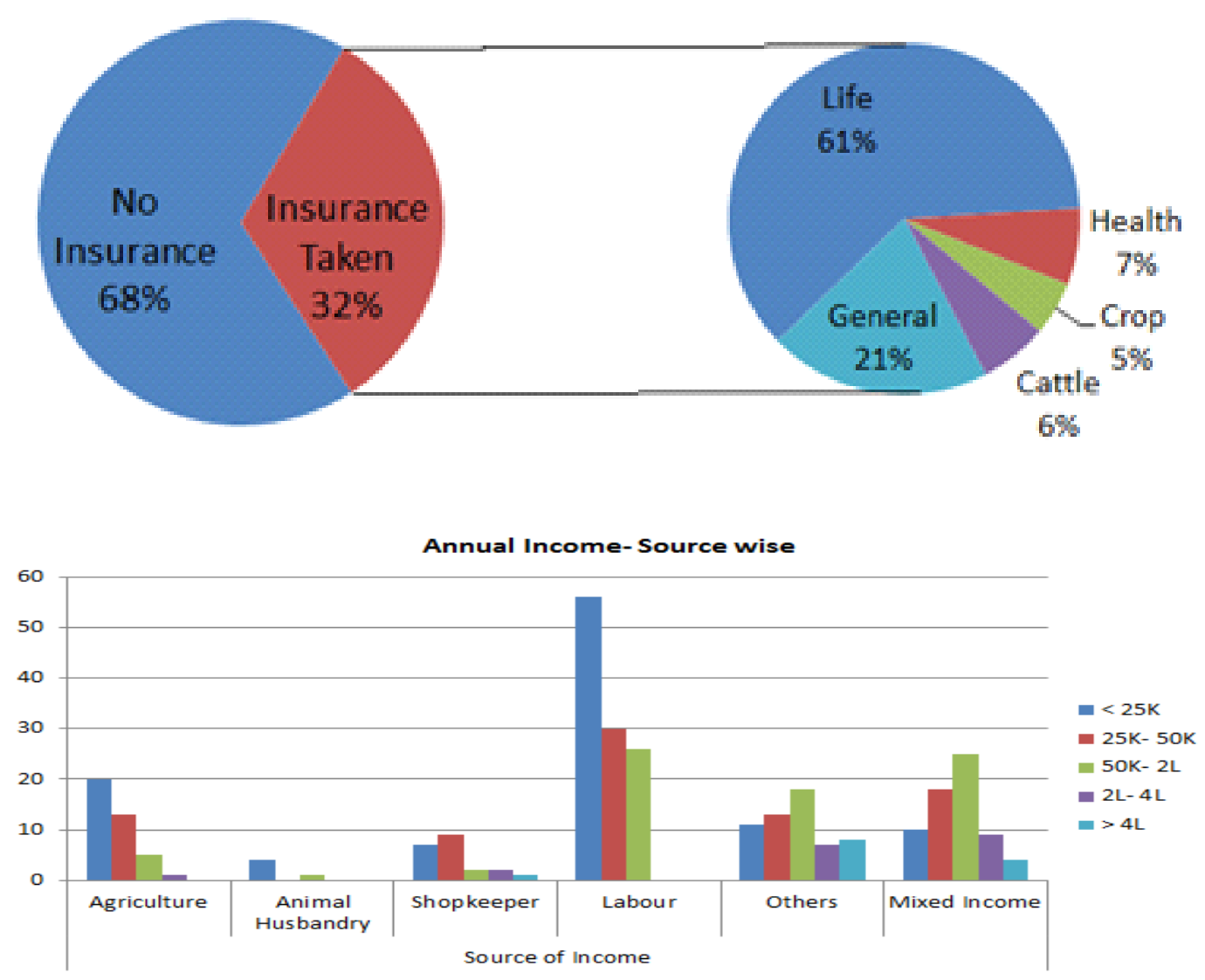
that funds from such government welfare schemes are meant to be for Above Poverty Line (APL) people in the administration of the village. They also told that KCC loans were being availed only by farmers who had large agricultural land holdings.

With low income, the surveyed respondents could hardly save any money. Hence, any financial product including deposits or insurance is a luxury for them and they can't afford for it. Low insurance penetration in the villages with only $30 \%$ people surveyed having any kind of insurance. Out of these, most had a life insurance policy with LIC. The biggest problem is lack of sufficient income and large family size. People are aware of the benefits of insurance. They lack trust on the banking system. Commoners are deprived of the benefits of welfare schemes by powerful people in their own villages.

PMJDY for Financial Inclusion: Till $1^{\text {st }}$ November 2017, 305.6 million beneficiaries banked so far under the scheme with ₹672.6472 billion balance in the accounts. 126 thousand Bank Mitras delivering branchless banking services in Sub-Service Areas and 229.7million Rupay Debit Cards issued to beneficiaries. One of the survey reported in English daily indicate that "The dominant reason for opening PMJDY accounts is to deposit savings, which is cited by $52 \%$ of account holders. The next highest reason $(23 \%)$ is to avail of insurance attached to the accounts, followed by the desire to avail of direct benefit transfers and subsidies (16\%)," These are very good for creating an environment for Financial Inclusion but until unless arrangement for regular income is made for all specially for BPL families along with the awareness campaign, complete and self-sustainable inclusion will not be possible.

\section{Summary:}

This study based on secondary and primary data concludes that there is a strong structural exclusion which has divided our economy into people with no income, low income and high income. There is a need to strengthen the financial infrastructure for delivery of financial services at the doorstep of all. However, the study finds through primary survey that the low income groups are even not able to utilize the existing financial structure due to lack of sufficient sustainable income. Government efforts can only open bank accounts for the poor but cannot make them active accounts. PMJDY has made remarkable penetration in terms of access of banking service and insurance products but until employment is generated for all and a guaranteed basic income is available on regular basis this menace of financial exclusion will not end. Hence, there is a need to alleviate poverty for achieving true financial inclusion.

\section{A. Conclusion:}

Our primary study and secondary data analysis show the main stumbling block in achieving financial inclusion is the Earning Capability. Thus, the focus of our study is towards

\section{S Income Generation Model:}

- There should be a Self-generating flow of income

- The income should be $\underline{\text { Sufficient }}$

- The income should be $\underline{\text { Sustainable }}$

This can be facilitated through:

- Infrastructure Development of warehouse facilities, irrigation facilities, movable market (e-choupals), movable banks, mobile banks etc.

- Government schemes like Jan Dan Yojna to increase the reach of banking facilities and provide benefits of insurance.

- Skill Development with focus on workforce of key industries and artisans in general

- Financial Awareness needs to be increased amongst the financially excluded by way of special initiatives

We, thus propose for a complete inclusion campaign to be in place, which will phase out subsidy over the years.

\section{B. Recommendations}

After extensive analysis of secondary and primary data, we identified the weak links in the current financial structure and suggested some ways in which these shortcomings can be corrected. Since financial inclusion is a macro level issue most of our recommendations are directed towards the central government. Some of them are as follows:

1. Enable the economy to create an opportunity for sufficient and stable income for all

2. Availability of Financial infrastructure like banks, ATMs, within reach (may be through the support of technology like internet and mobile banking).

3. Leakage of financial benefits in transit between policy desks to public pocket.

4. Awareness and availability of the financial products like Deposits, Insurance, Pension fund, overdrafts, bank loans etc.

5. Relaxation in ' $\mathrm{KYC}$ ' norms to make the financial products and services available conveniently to small and marginal farmers and low-income households at reasonable cost with adequate protection progressively supplemented by social cash transfer.

6. Encouragement and motivation to use the financial products on regular basis.

Government is actively engaged in addressing the point number 2 to 6 of the above recommendations through JanDhan Yojna, AAdhar Card and Mobile banking (JAM); DBT but the biggest bottle neck is first point i.e. creation of job opportunities. MGNREGA tried in very limited and in- 
effective way to attend that issue. Make -in -India and National Skill Development Corporation (NSDC) might bring some change at this front.

\section{Scope for further study:}

This Study talked about the importance of financial inclusion and highlighted various policies that have been adopted in India to increase the same. Our study shows that Indian Government has taken various steps towards Financial Inclusion but the same haven't bore fruition vis-a-vis the efforts. Given the diversity and complexities in the demography of India, the successful global financial inclusion models can't be applied in isolation. Thus, the study suggests to take a modular approach towards increasing Financial Inclusion in India, especially in the most financially backward states like Odisha, Bihar, Jharkhand, Chhattisgarh etc.

\section{REFERENCES:}

[1] Arulmurugan P, Karthikeyan P, Devi N., (2013). Financial Inclusion in India: A Theoretical Assessment. Indian Journal of Applied Research. 3 (3).

[2] Jeromi, P.D., (2007). Regulation of Informal Financial Institutions: A Study of Money Lenders in Kerala. Reserve Bank of India Occasional Papers. 28 (1)

[3] Krishnakumar, R \& Vijayakumar, L. (2013). The Effectiveness of the Financial Inclusion Products. IRACST - International Journal of Commerce, Business and Management (IJCBM), ISSN: 2319-2828 Vol. 2, No.6, December 2013, pp 457-466.

[4] Kumar Kabir, Merchan Camilo (2013). What Role Startups Play In Financial Inclusion? Available at: http://www.cgap.org/blog/whatrole-start-ups-financial-inclusion.
[5] Kumar Pankaj, Golait Ramesh, (2009). Bank Penetration and SHGBank Linkage Programme: A Critique. Reserve Bank of India Occasional Papers. 29 (3), pp.1-15

[6] Misra, Udit (2010). Financial Inclusion Models From Around The World. Available at: http://india.forbes.com/article/financialinclusion/financial-inclusion-models-from-around-the-world/19292/1.

[7] Malegam, Y. H.(2011), Report of the Sub-Committee of the Central Board of Directors of Reserve Bank of India to Study Issues and Concerns in the MFI Sector.

[8] Nachiket Mor (2014), Report of the Committee on Comprehensive Financial Services for Small Business and Low Income Households, Reserve Bank of India.

[9] Porkodi S,Aravazhi D.,(2013). Role Of Microfinance \& SHG in Financial Inclusion.International journal of marketing,financial services \& management research, 2(3).

[10] Rangarajan,C.,Committee (2008), Report of the Committee on Financial Inclusion, Government of India.

[11] Raghuram G. Rajan (2009), "A Hundred Small Steps - Report of the Committee on Financial Sector Reforms"

[12] Sarma Mandira, Pais Jesim, (2009). Financial Inclusion and Development: A Cross Country Analysis . ICRIER Working Paper.

[13] Sengupta, Santanu (2009). Speeding Financial Inclusion Through BCBF Model: Issues, Challenge \& Oppurtunities.

[14] Shah, Ajay.(2010), Report Of The Expert Committee On Harnessing The India Post Network For Financial Inclusion, Government of India.

[15] Sharma Anupama, kukreja Sumita, (2013). An Analytical Study: Relevance of Financial Inclusion For Developing Nations. Research Inventy: International Journal Of Engineering And Science, pp.15-20.

[16] Singh, Ravindra. \& Nisha, (2014). Financial Inclusion and Economic Growth in India - A Theoretical Framework, International Research Journal of Management Sociology and Humanity (IRJMSH), Volume 5, Issue 5, online ISSN 2277-9809, pp 131-138.

[17] Thapar, Ashima, (2013). A study On The Effectiveness of The Financial Inclusion Program in India. VSRD International Journal Of Business \& Management. 3 (6), pp.211-216. 